\title{
Effect of sago starch and plasticizer content on the properties of thermoplastic films: mechanical testing and cyclic soaking-drying
}

\begin{abstract}
Studies on the effect of sago starch and plasticizer concentrations on the tensile and tearing properties of the produced starch films were carried out using universal testing machine. The results showed that both sago starch and plasticizer contents significantly affected the mechanical properties of starch films. With increasing the starch concentration, an increase in tensile strength was observed. This was accompanied by radically reduced tensile strain and increased tearing strength. On the contrary, when increasing the plasticizer concentration, a reduction in tensile and tearing strength was observed, as well as an increment in tensile strain. The results of repeated soaking and drying tests made on sago starch films showed that the films with high plasticizer and low starch content exhibited lower mass loss compared to those containing lower plasticizer and higher starch concentration. Increasing the number of soaking and drying cycles reduced starch dissolution and it was probably related to retrogradation process inside the film. In a nutshell, the study provided preliminary information to assess the possible application fields of sago starch films.
\end{abstract}

Keyword: Sago; Starch; Tensile; Tearing; Water absorption; Crystallinity; Film sago; Skrobia; Rozciąganie; Rozrywanie; Absorpcja wody; Krystaliczność; Błona 